\title{
PRELIMINARY NOTE ON THE SOCALLED RECOVERY OF THE CANE VARIETY B. 34104 FROM THE SUGARCANE MOSAIC VIRUS IN PUERTO RICO
}

According to Martyn, reporting from Jamaica ${ }^{1}$, sugarcane varieties B. 34104 and B. 37161 are unaffected by the sugarcane-mosaic virus found there. He further states, still referring to B. 34104, that "unfortunately the leaf symptoms, often not very distinct on this variety, vanish almost entirely as the cane matures."

Because of their excellent agronomic qualities these two canes, especially B. 34104, have been increasing in popularity with the growers of the Island. Many of our farmers believe that the sugarcane variety B. 34104, although susceptible to mosaic, can produce more sugar than the currently known commercial varieties and, what is more, that this variety recovers from the disease.

The first claim has been amply refuted now by the experiments of González and Adsuar ${ }^{2}$ which clearly demonstrated a reduction of 30 percent in tonnage of cane and of 34 percent in the total sugar produced when diseased was compared with healthy cane.

The following experiment was performed to clarify the second claim, that is, that B. 34104 and B. 37161 recover from mosaic. Single three-eyed cuttings taken from healthy stools of both varieties were planted in 6 -inch pots. When the plants were about 10 inches high they were inoculated on the leaves by rubbing with carborundum, using as inoculum juice extracted from variety B. 10-12 infected with moasic. Sorghum (Holcus sorghum L.) seedlings ${ }^{3}$ were inoculated as checks to test the infectiousness of the juice. When symptoms developed on the inoculated canes they were taken to the field and planted in two rows 6 feet apart, 21 plants per row, the plants also being 6 feet apart in the row.

About 6 months later the field was inspected and it was found that five plants of B. 34104 and three plants of B. 37161 had apparently recovered from the disease. To test the possibility that, although not showing symptoms, the recovered canes might carry the virus in a latent or masked form, juice was extracted from leaves of each recovered cane and inoculated on sorghum seedlings. The inoculations were repeated at least twice. None of the sorghum seedlings inoculated with juices extracted from the different recovered B. 34104 and B. 37161 canes showed symptoms of mosaic. It was concluded that the plants had recovered fully and that the virus was

1 Martyn, E. B., Sugar cane mosaic in Jamaica, Trop. Agr. 23 (7) July 1946.

2 González Ríos, P., and Adsuar, J., Effect of mosaic on the yield of sugarcane variety B. 34-104, J. Agr. Univ. P.R. 37 (1) 13-8, 1953.

${ }^{3}$ Adsuar, J., On the physical properties of sugarcane mosnic virus, Phytopath. 40 (2) 214-6, 1950. 
absent from their tissues insofar as biological means of detection, using a highly susceptible host, was concerned.

However, it was considered of interest also to determine whether the recovered canes were still susceptible to reinfection. Cuttings taken from the recovered canes of both varieties were brought to the greenhouse, planted, and inoculated as described above with infective juice from the same source as was used in the previous inoculations. All the plants grown from cuttings from recovered canes show symptoms of mosaic when inoculated with sugarcane mosaic virus.

As a result of these preliminary experiments it is concluded that varieties B. 34104 and B. 37161, may recover to some degree from mosaic, but ${ }^{2}$ the recovered canes are still susceptible to reinfection by the sugarcanemosaic virus.

J. Adsuar

Department of Plant Pathology 